\title{
Exploring the Boundaries of Distance Learning in Ocean Environments
}

\author{
Robert D. Ballard \\ Institute for Exploration - Mystic, Connecticut USA \\ Stephen M. Coun \\ JASON Foundation for Education - Walthan, Massachusetts USA
}

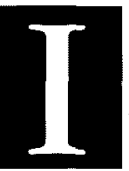

n April 1998, the JASON Project joined a team of researchers bound for Guaymas Basin in the Sea of Cortez, Mexico, aboard the R/V Atluntis. The mission was to conduct scientific research on hydrothermal vents and the surrounding biological communities at the bottom of the sea. During the expedition, daily reports, data, and images were sent from the ship using a satellite link to the Internet, allowing JASON Project students to follow the expedition along with shore based scientists. The Guaymas basin expedition was the culmination of the ninth JASON Project, "Oceans of Earth and Beyond" during the 1997-1998 academic year. Approximately 1,000,000 middle school students and 25,000 teachers studied shallow, mid, and deep ocean environments through a comprehensive curriculum, professional development programs for teachers, satellite and Internet programming, and videotapes. The project compared ocean environments in Bermuda, Monterey Bay, and the Sea of Cortez, (image 1.1 from the JASON website, Www.jasonproject. org).

Each researcher on board Atlantis, along with many members of the ship's crew contributed to this online expedition and journal. Information was gathered and organized to help place it within the context of the curriculum and educational media developed by the JASON Project. Dr. Gene Feldman, an oceanographer with NASA's SeaWIFS Project and two teachers, Leonor Gonzalez and Dora Blaine led this effort from the ship. Todd Viola managed operations stateside. Disciplines covered in-depth included mapping and navigation, technology, vent ecology, microbiology, and geochemistry.

The NOPP supported components of the JASON IX program, especially the partnership with key research organizations participating in the Atlantis expedition, allowed the JASON Project to make major advances in three areas of significance to marine science education in particular, and distance learning in general. NOPP was a catalyst for bringing diverse parties together, linking researchers, educators, and organizations focusing on the implementation of new technologies. First, the shipboard expedition was a major demonstration of the efficacy of Internet based technologies from a remote location. Efficacy in this case includes the ability to provide continuous student access to the expedition and interactivity with the researchers. Second, the Atlantis expedition allowed JASON to develop and implement more mobile and cost effective distance learning strategies, with interaction, than traditional electronic field trips to remote locations which have been heavily dependent upon satellite and broadcast technologies. Third, NOPP facilitated collaboration with several institutions such as the University of Nebraska-Lincoln and the University of Wisconsin-Milwaukee to provide broader access to the JASON Project for students and teachers in traditionally underserved areas of the nation. Prior to NOPP funding distribution of JASON was somewhat limited, particularly in landlocked states such as Nebraska.

For the past ten years the JASON Project has dereloped as both an interdisciplinary science education program and a demonstration of the uses of technology within classrooms. This has been accomplished in large part through linkages with the scientific community, and by demonstrating how technology is transforming scientific research. The JASON Project's educational approach uses hands-on learning and builds upon what Carey (1989) calls the "construction of sci- 
entific knowledge." Duschl (1990) notes the importance of engaging students in understanding the development of theory through active inquiry processes within the learning environment. All JASON content seeks to engage students in the development of theory and to model the scientific process from the point of asking theoretical questions through choice of technology for data collection, and then onto the analysis and implication scenario stages. Currently, few models emphasize the large-scale use of personal technologies in assisting students in actively engaging in real-time scientific research, in closely examining the implications of variations in data collection, or in developing models from data as an easily accessible teaching and learning tool.

JASON's professional development is based on the framework detailed in the National Science Education Standards. This framework emphasizes continuous exposure to scientific content. As Little (1993) points out, one of the great challenges with this approach is helping teachers see relevancy or "fit" within a standards environment. JASON's professional development approach is designed to assist teachers in gaining a better understanding of how they are teaching within a standards-based environment, while simultaneously providing rich content that can be put to use immediately. The long-term challenge for national teacher professional development programs like JASON is to be able to continue providing rich content, while assisting teachers in understanding the use of emerging technologies as tools for scientific research and discovery. Over the next two decades, $\mathrm{K}-12$ schools are expected to hire roughly 2 million new teachers to fill vacancies left by retiring teachers and accommodate an increase in the student population. While studies show that teachers recognize that computers and advanced communications technologies offer new and exciting possibilities for learning, (CEO Forum, 1999) only $20 \%$ report feeling "very well prepared" to integrate educational technology into classroom instruction (U.S. Office of Technology Assessment, 1987). Meanwhile, U.S. schools of education have only just begun to focus on preparing future teachers to understand, access, and integrate technology-based experiences into the learning process (Means, 1994).

Recent reports from the United States Department of Education and other sources indicate that remarkable progress has been made during the past five years in connecting schools to the Internet. The Department of Education reported in late 1999 that while only $3^{\circ}$ o of America's classrooms were connected to the Internet in 1994, the number jumped to $63 \%$ in 1999. The Department of Education also reported that $69^{\circ}$ in of teachers use a computer daily for some aspect of instructional planning or delivery, an increase of $22 \%$ from the previous year (U.S. Department of Education, 1999).

With support from NOPP, the JASON Foundation for Education participated in an independently sup- ported research cruise aboard Atlantis involving the Remotely Operated Vehicle (ROV) JASON and deep submergence vehicle ALVIN. Researchers on this expedition studied the Guaymas Basin area. This effort was part of the JASON IX oceans program, a year-long celebration of the International Year of the Ocean. The JASON Project curriculum, interactive Internet components, and field research opportunities for students produced for this expedition were linked with the research being undertaken by scientists aboard the Atlantis. Participating students also studied deep-sea structure, marine chemistry, and geological and biological oceanography.

JASON IX featured research on deep-water and midwater systems within Monterey Bay, including sea surface mapping of phytoplankton, acoustic sensing of organisms within the water column, tectonic and hydrologic studies of deep-water venting systems, geochemical analysis of bottom substrate, mid-winter ecology $(1 \mathrm{~km})$ above Monterey Canyon, deep-sea benthic bacterial studies, and benthic ecology of Monterey Canyon and cold seep ecology.

JASON IX also featured research conducted on site in Bermuda. Students learned about the island's diversity of habitat sites. Generally nutrient poor, these sites include blue-water/deep-sea, slope, mid-water, coral reefs and surface systems. Researchers illustrated their studies on nutrient cycling, including phytoplankton circulation and geochemical analysis, water quality, and mid- and deep-water ecology, including bacteria, zooplankton, protozoan and larger organisms (via acoustic sensing). Each research program was incorporated into the Bermuda Atlantic Time Series (BATS) program which monitors each of the different habitats over time and provides a global perspective of change including climatic change. Additional affiliated research activities include preservation of an island and its original inhabitants (among which are many seabirds which were believed to be extinct), freshwater quality, karst limestone caves, and acoustic research on humpback whales.

The research conducted on this expedition highlighted the structure of the oceans, showing middle schools students that they consist of shallow-, mid-, and deepwater systems. Students learned about the surface, pelagic, and benthic components of each system and the different habitats that can be found within each component, based on the variability of the substrates and nutrients available. For example, comparisons were made between the nutrient-poor systems of Bermuda, including coral reefs which recycle nutrients efficiently, the eutrophic condition of Monterey Bay, and the active conditions of the East Pacific Rise. Students also observed how monitoring these systems could provide a general understanding of global change within the oceans and the oceans' role in climate change.

NOPP support allowed the JASON Foundation to broaden the delivery of live, interactive expedition activities to include direct Internet access by students at 
schools throughout the United States to remote research locations. This effort augmented the existing satellite telecast to accommodate and promote the increased levels of interaction now possible through the Internet. For the Guaymas Basin expedition, the JASON Foundation used the Internet to provide students with a virtual window into the researchers' world on board Atlantis. The JASON Foundation facilitated an active communication between working scientists and the students, allowing students to actually access and analyze the expectition's emerging data.

To accomplish this kind of communication, the JASON Foundation worked with another NOPP sponsored project called SeaNet in designing and implementing the system necessary to capture the researchers' data and provide students with access to it via the Internet. SeaNet has developed a platform for extending the Internet to ships at sea. Data are sent from the Jason robot's fiber optic cable for processing by researchers on board the Atlantis. SeaNet uses three data pipes or directories of information, which are sent by satellite to specific locations on shore, including the educational programming developed by the JASON educational website.

Dr. Gene Feldman explained the SeaNet system to JASON students in a posted message on the JASON website during the expedition. He wrote:

\section{Using SeaNet, science is being conducted in a new and exciting roay during this expedition. Seanet allows scientists onboard Atlantis to send large amounts of data to researchers on land. By laving immediate access to this information, the number of people inolved in work taking place at sea is great- ly increased.}

Ensuring that schools had the ability to access and interact with the expedition on the Internet was critical. Well in advance of the expedition, the JASON Foundation prepared and posted on its Internet website www.jasonproject.org, technical support materials for students and teachers who planned to participate in the interactive Internet component of the expedition. Guidance was also provided to assist project participants in downloading StreamWorks, a software application which enables schools to receive live audio and video images through the Internet.

Significantly, K-12 education was always viewed as an integral component of the Atlantis expedition. However, the educational aspects of the voyage were not the only purpose for the ship's cruise to Guaymas Basin. Dr. Gene Feldman detailed the process of how the research team reached consensus on how to conduct the expedition to accommodate various agendas and needs. In his daily journal to students via the JASON website, Dr. Feldman wrote:

Before we put (the ROV) JASON in the water for the first dive, there anas a meeting of all members of the expedition in the ship's library to discuss the objectives of the dive and to make sure that everyone lad a common understanding of allat we were trying to do and when and why are zeanted to do it... With many scientists all wanting to look at sometimes different things, there could be the potential for misunderstandings. . . Much discussion revolved around what the "ideal" site would be to satisfy the greatest number of scientist's objectives. .. The plan was to lower (the ROV) JASON within the same general area that it wisited back in 1993 during JASON Project $I V$.

This scenario allowed the JASON Project to build upon a vast array of educational resources developed during the JASON IV expedition. In addition, the entire Guaymas Basin education program fit within an extensive educational and research infrastructure developed by the JASON Foundation for Education and its partners for implementation during the 1997-98 school year.

With the help of SeaNet, for the first time, the JASON Project expanded the scope of its expeditions by enabling students and teachers to follow researchers in great detail on board a research vessel as a kind of culminating event for the academic year. Traditionally, JASON Project expeditions have presented students and teachers with broad levels of information about the expedition sites and the research approaches of participating scientists through live telecasts and specific activities that link to the Project's themes. Past projects have not, however, included a post-expedition component that allows participants to continue to follow the work of scientists once they return to work at their laboratories and research institutions.

Essentially, the Guaymas expedition produced a rich array of data and images that are archived and contintue to be used by students and teachers participating in the JASON Project. For example, researcher Jonathan Howland described for students on the JASON Website a tall sulfide structure found underwater that was the subject of several days of observation by him. While the story is compelling, the significance of the structure is better explained to students through a photomosaic, a collage of separate images put together into a larger picture. The photomosaic, (Figure 1) was developed by the researchers on board Aquarius III and served both an important research function and an invaluable educational experience when it was posted on the JASON website. 
In order to further experiment with the idea of following researchers in their own settings, a network of web cams were launched at key research locations, including Mote Marine Laboratories in Sarasota, Florida and the Bermuda Biological Research Station. The web cams have proven to offer more challenges in implementation, deployment, and educational relevance than originally envisioned. The challenges include unpredicted costs of launching and using the units especially for the host institutions. Another challenge has to do with determining where the web cams will be located. This issue relates to the relevance of the web cams within the overall educational experience.

To a large extent web cams provide static or fixed images of a particular location. When the JASON Project introduced the world's first underwater web cam on board the research station Aquarius in 1996, the novelty of the concept attracted considerable attention, particularly among students and teachers. That year the web cam operated within the context of the expedition curriculum supported by other programming and web components. What the JASON Project discovered in implementing web cams at Mote Marine Laboratories and Bermuda Biological Research Station in 1998 was that simply following a researcher, research project, or keeping a web cam on one particular object or location without curriculum, additional programming, and context, has limited educational value or appeal.

The irony of this experience is that it brought JASON full circle to the challenges that the effort faced during the first JASON expeditions in the early 1990's. Then, JASON utilized new kinds of technologies to generate live satellite images from undersea locations and transmit them back to a network of auditoriums throughout the world. A highly limited number of students interacted with research scientists via telephone and by driving remotely operated rehicles. Evaluation of these early programs revealed that in order to reach larger numbers of students effectively and to have measurable impact on teaching and learning, dazzling technology and "you are there" imagery were not enough.

Throughout the mid-1990's the JASON Project developed what became known as the "integrated curricular approach" which combined curriculum, professional development, video, broadcast technologies, and eventually Internet programming to create a comprehensive educational experience. The question was not how to bring technology into the curriculum, but when to use it in a way that enhances the teaching and learning experience. Within the JASON Project teams of educators, broadcast production personnel, technologists, and professional development specialists labored to break down traditional disciplinary barriers and approaches to particular media. For example, the idea that every topic covered during the live broadcast should also be covered within a printed curriculum was abandoned. Likewise, the idea that the website was the place to cover material that did not fit elsewhere was also abandoned. Instead, a comprehensive planning matrix was established to create educational surround, context, and themes related to particular aspects of science. The question became not where to cover certain topics, but how to cover them, and how to best utilize particular media so that printed curriculum enhances but does not replicate web based curriculum or broadcast based experiences.

A key aspect of this effort involved NOPP partnerships with business and academia. Building upon the growing body of educational knowledge that JASON was accumulating through the Guaymas Basin expedition and efforts to implement web cams, JASON undertook a major revitalization of its award-winning website. Spurred on by the NOPP effort, Sprint became a major partner and provided extensive in kind technical support. The redesign of the JASON Project website focused on giving students and teachers a better understanding of the context of experiences such as the Guaymas Basin cruise as well as more interactive curricular experiences. By developing this capacity online, the educational merit and value of technological experiences that were now possible through the use of web cams' chat sessions, image sharing, and Geographic Information Systems (GIS) was vastly increased. Through the use of an integrated curricular approach, participating students developed their own research projects related to the oceans that fit within the research being conducted as part of the larger JASON expedition.

One partner in the project, The University of Nebraska at Lincoln, designed and delivered an accredited high school course on ocean science through its Communications, Learning, and Assessment in a Student-centered System (CLASS) Project partnership. This university-based, fully accredited independent study high school is the only such institution in the United States. CLASS is a unique project designed to allow students worldwide to take interactive University of Nebraska-Lincoln high school and college courses via the World Wide Web. For this project, the JASON Foundation collaborated with the University of Nebraska's independent study high school to develop an ocean studies course that incorporated electronic interaction among students, instructors, field researchers, and other external resources. The program was designed to encourage independent learning by allowing students to personalize courses and explore paths through a variety of materials, including global digital libraries, video and audio clips, and customized course materials.

Another project partner, the University of WisconsinMilwaukee established an Internet based for-credit course in ocean science. To design the course, University of Wisconsin curriculum developers collaborated with both the JASON Project curriculum team and the expedition scientists to design a professional development program for teachers of science. Using the expedition site as a case study, the course covered deep- 
sea structure, marine chemistry, geological and biological oceanography, and the development of hydrothermal systems. The course also provided teachers with training in the development and use of innovative strategies for effectively presenting ocean-based curriculum materials in the classroom.

The course consisted of text and video lectures, video clips, and audio sequences accessible through the JASON Project's website to enrolled teachers. The course also consisted of chat sessions among teachers and researchers and provided participants with a host of related resources upon which they could draw for assignments and reports. Teachers enrolled in this program also developed, submitted, shared, and discussed lesson plans for course credit with their
In partnership with NOPP, the JASON Foundation has established stateroide presence and interactive capabilities in Rhode Island, Connecticut, Nebraska, Massachusetts, and Mississippi.
NASA-Johnson Space Center (Houston, TX), the Denver Museum of Natural History, and the University of Wisconsin-Milwaukee. These sites recruit teachers and schools to participate in JASON expeditions, host professional development workshops for teachers, show the expedition broadcasts for large groups of students, and offer other services depending on their capabilities. Connecticut and Florida include JASON expedition broadcasts and other JASON programming on their statewide networks, available to all classrooms by broadcast or video.

In summary, the JASON Project was able to advance understanding relating to the development and implementation of new distance learning technologies through its partnership with NOPP. Significant progress was made in building new tools and approaches. However, the creation of new technologies such as web cams are only important educationally when they are placed within the context of curriculum, professional development, and used in ways that enhance the teaching and learning of key concepts and disciplines. the success of any educational endeavor today. In partnership with NOPP, the JASON Foundation has established statewide presence and interactive capabilities in Rhode Island, Connecticut, Nebraska, Massachusetts, and Mississippi. In addition, California, Wisconsin and Florida benefited directly from this project through support for institutions of higher education, and outreach programs.

The JASON Foundation has significantly increased each state's capacity to receive the full range of JASON IX program components for the Guaymas Basin expedition. Specifically, teachers in these states will be able to participate in professional development opportunities offered through the University of WisconsinMilwaukee as well as local workshops. Students gained access to both the satellite and Internet-based components of the program, including the live satellite telecasts, Internet access during and after the expedition, and distance-learning opportunities offered through the University of Nebraska at Lincoln.

JASON also has a variety of partners that deliver JASON programming and provide educational support on a regional level, including Primary Interactive Network Sites (PINS) and the Florida and Connecticut state departments of education. PINS include educational, research, and cultural institutions such as the Clark County School District (Las Vegas, NV), the

\section{REFERENCES:}

Carey, S., 1989: A Study of Grade 7 Students' Understanding of the Construction of Student Knowledge. International journal of Science Education, $11(5)$.

CEO Forum on Education and Technology, 1999: School Technology and Readiness Report. Professional Decelopment: A Link to Better Learning. Washington D.C. (Www.CEOFORUM.org)

Duschl, R.A., 1990: Restructuring Science Education: The Importance of Theorics and Their Development. Teachers College Press, New York, New York.

Little, J.W., 1993: Teachers' Professional Development in a Climate of Educational Reform. Educutional Evaluation and Policy Annlysis, 15 (2).

Means, B., 1994: Techiology and Education Reform: The Reality Behind the Promise. Jossey Bass, San Francisco, California.

United States Office of Technology Assessment, 1987: Pouer On! New Tools for Teaching and Learning.

United States Department of Education, National Center for Education Statistics, 1999: Teacher Quality: A Report on the Preparation and Qualification of Public School Teachers. 